\title{
COVID-19 and the Promotion of Digital Competences in Education
}

\author{
Maria José Sá ${ }^{1}$, Sandro Serpa ${ }^{2,3,4, *}$ \\ ${ }^{1}$ CIPES-Centre for Research in Higher Education Policies, Matosinhos, Portugal \\ ${ }^{2}$ Faculty of Social and Human Sciences, Department of Sociology, University of the Azores, Portugal \\ ${ }^{3}$ Interdisciplinary Centre of Social Sciences - CICS.UAc/CICS.NOVA.UAc, Portugal \\ ${ }^{4}$ Interdisciplinary Centre for Childhood and Adolescence - NICA - UAc, the Azores, Portugal
}

Received June 15, 2020; Revised July 28, 2020; Accepted August 25, 2020

\section{Cite This Paper in the following Citation Styles}

(a): [1] Maria José Sá, Sandro Serpa , "COVID-19 and the Promotion of Digital Competences in Education," Universal Journal of Educational Research, Vol. 8, No. 10, pp. 4520-4528, 2020. DOI: 10.13189/ujer.2020.081020.

(b): Maria José Sá, Sandro Serpa (2020). COVID-19 and the Promotion of Digital Competences in Education. Universal Journal of Educational Research, 8(10), 4520-4528. DOI: 10.13189/ujer.2020.081020.

Copyright $\mathrm{O} 2020$ by authors, all rights reserved. Authors agree that this article remains permanently open access under the terms of the Creative Commons Attribution License 4.0 International License

\begin{abstract}
The pandemic caused by COVID-19 has profound consequences on social, economic and cultural life worldwide, and is affecting, throughout the world, the regular functioning of educational institutions at all levels, with their temporary shutdown and the impossibility of face-to-face classes. This study aims to add to the analysis of the implications of this context in the reformulation of education shaped by the digital. To fulfill this goal, the authors carried out a document collection, and also mobilized their experience in the research and teaching of this topic. It is concluded that these unforeseen circumstances may be a key moment of opportunity for reformulating teaching, with the implementation, development and dissemination among teachers and students of digital technologies in shaping a society that is, itself, increasingly digital, notably Society 5.0. To this end, and as main implications, the agents of the educational process, teachers and students, due to their traits and various reasons, will have to prepare for student-centered learning through the intentional and sensible mobilization of digital technologies in a complex process, in which each agent will be, ultimately, a critical content creator with enhanced digital literacy. In the contemporary digital society, the school needs to reinvent itself, which is even more pressing with the Covid-19 pandemic. Aspects such as training, internet access infrastructure, hardware and software, digital literacy, and students and academics' teaching and learning strategies are essential. The school offers, thus, a critical contribution to social cohesion and social equity through digital inclusion in education for
\end{abstract}

sustainable development.

Keywords COVID-19, Digital Competences, Online Learning, Student-centered Learning, School, Education

\section{Introduction}

The pandemic caused by COVID-19 (Severe Acute Respiratory Syndrome Coronavirus 2, SARS-CoV-2) had and will continue to have profound implications at the global level, with the difficulty of predicting, with some degree of certainty, its repercussions and future consequences. Several countries have been adopting measures to mitigate the impact of the epidemic. Among these measures, we highlight (1) social distancing (especially the immediate isolation of people with symptoms, the suspension of mass meetings, social distancing in the workplace and schools shutdown); (ii) citizens' awareness of the severity of SARS-CoV-2; (iii) the prevention and control of COVID-19 in hospitals and other healthcare facilities; (iv) training of all healthcare facilities' staff; (v) rationalization of the use of limited resources; and (vi) creation and implementation of surveillance systems to detect cases and assess the transmission of the virus among populations [1].

Some of these containment measures, social isolation and confinement in the context of the fight against the spread of the coronavirus also focused on the area of 
education. These measures include, among others, the suspension of face-to-face classes and student tutorial support. These activities, previously carried out mostly in person, began to be developed via the Internet, in a context in which digital, as well as classes broadcasted through television, became the only means of interaction between teachers and students [1]. This challenge of living and coexisting, at least for several months, with a contingent situation caused by COVID-19, can also be viewed as shaping the need for adaptation, but - and especially - as opportunities and new challenges for educational institutions.

In a context in which the pandemic caused by COVID-19 has had profound consequences on social, economic and cultural life worldwide, in an increasingly digital society [2,3], with the announced Society 5.0 based on digital being a paradigmatic example $[4,5]$, the schooling dimension has also been affected in its normal functioning $[6,7,8,9,10,11,12]$.

In this paper, we advocate that these conditions can be a critical moment of opportunity for the reformulation of higher education, with the implementation, development and dissemination, among teachers and students, of digital technologies, enabling personal and social development in a sustainable society [13].

Digital competences are also vital for sustainable development [14]. Cantabrana, Minguell, and Tedesco [15] (p. 44) maintain that "education has a prominent role in promoting inclusion and social integration and helping citizens to develop the competences they need to access, record, edit, publish and share online content autonomously, judiciously and responsibly".

For this analysis of the potential relationship between the COVID-19 pandemic and the promotion of digital competences in education, we will analyze the improvement of digital competences in education, focusing on the following topics: (i) school culture; (ii) digital competences; and (iii) promotion of digital literacy through education. The paper closes with the main conclusions from the research.

\section{Improvement of Digital Competences in Education}

\subsection{School Culture}

School organizations are extremely complex because they deal with individuals and aim at their education/training $[16,17,18,19,20]$, and the specific organizational culture is a key feature to consider in the functioning and potential educational change in the organizational context $[21,22,23,24]$. Ozcan and Ozturk [25] (p. 46) sum up organizational culture and its consequences in the organization as follows:

"Organizational culture is known to have an impact on both how employees respond to change as well as the level of their resistance to it. Under circumstances of change, managers must demonstrate openness to novelty and work out ways to get through their teams " phases of resistance to change. Every organization owns a culture unique to itself. Made up of written or unwritten rules, beliefs and values, the organizational culture brings together individuals of differing opinions, beliefs, and values around a shared goal and thus helps the organization attain its goals".

In terms of school culture, it is a distinctive feature of each school, that is, all schools have a culture of their own. School culture may be defined as the set of "stable, underlying social meanings that shape beliefs and behavior over time" [26] (p. 8). It is a complex concept that entails backgrounds, traditions and rituals that are part of and shape the institution's history.

Strong school culture has numerous advantages, such as fostering performance and success, promoting the motivation of teaching and non-teaching staff, as well as students' and encouraging all the institutional actors to identify with the institution [27]. This is, thus, a key concept in the success of the school as an organization, having always underlying the sense of community.

\subsection{Digital Competences}

The digital competence - or digital literacy - is pivotal in contemporary social digitalization and should be promoted at all educational levels. It entails the capacity of using digital technology in fostering conscious civic participation in multiple dimensions $[13,28,29,30]$, and sustainability is one of these dimensions [31].

The literature offers several definitions of the capacity to mobilize the digital $[32,33]$. One of these definitions advocates that the Digital Competence "required when using ICT [Information and Communications Technology] and digital media to perform tasks; solve problems; communicate; manage information; collaborate; create and share content; and build knowledge effectively" [34] (pp. 3 and 4). This implies the ability to use digital technology, but consciously and critically [33]. The digital competence encompasses the ability to use, both as a consumer and as a content creator, digital technology, both in public and private life [13,28,35,36,37].

The need for digital competences is central to shaping the participation of individuals from different conditions in social, age, gender and even disability terms in this society $[13,38]$. In the teaching-learning process across the entire educational system, there is a lack of digital competences, which is an obstacle to learning and attaining these same competences based on the use of technologies and e-learning [39] and it is, potentially, a critical element in reducing the digital divide $[9,15,39]$.

In the report Promoting Effective Digital-Age Learning, Kampylis et al. [38] advocate the relevance of being a European reference framework that allows comparability 
to be used across all European Member States in the educational arena. Thus, the European Framework for Digitally-Competent Educational Organisations (DigCompOrg) seeks to be a trans-national systemic approach for European organizations to assess their digital capacity. This framework is composed of seven key elements and fifteen inter-related sub-elements that are common to all educational sectors across the Member

\section{States (Figure 1).}

Gomez Zermeño [40] argues that the presence of the Internet is unavoidable in contemporary life. Some authors even speak of a digital society, for example, "Society 5.0": a super-smart society. Society 5.0 emerges as a result of a technological revolution, which will have effects in all spheres of citizens' lives [41].

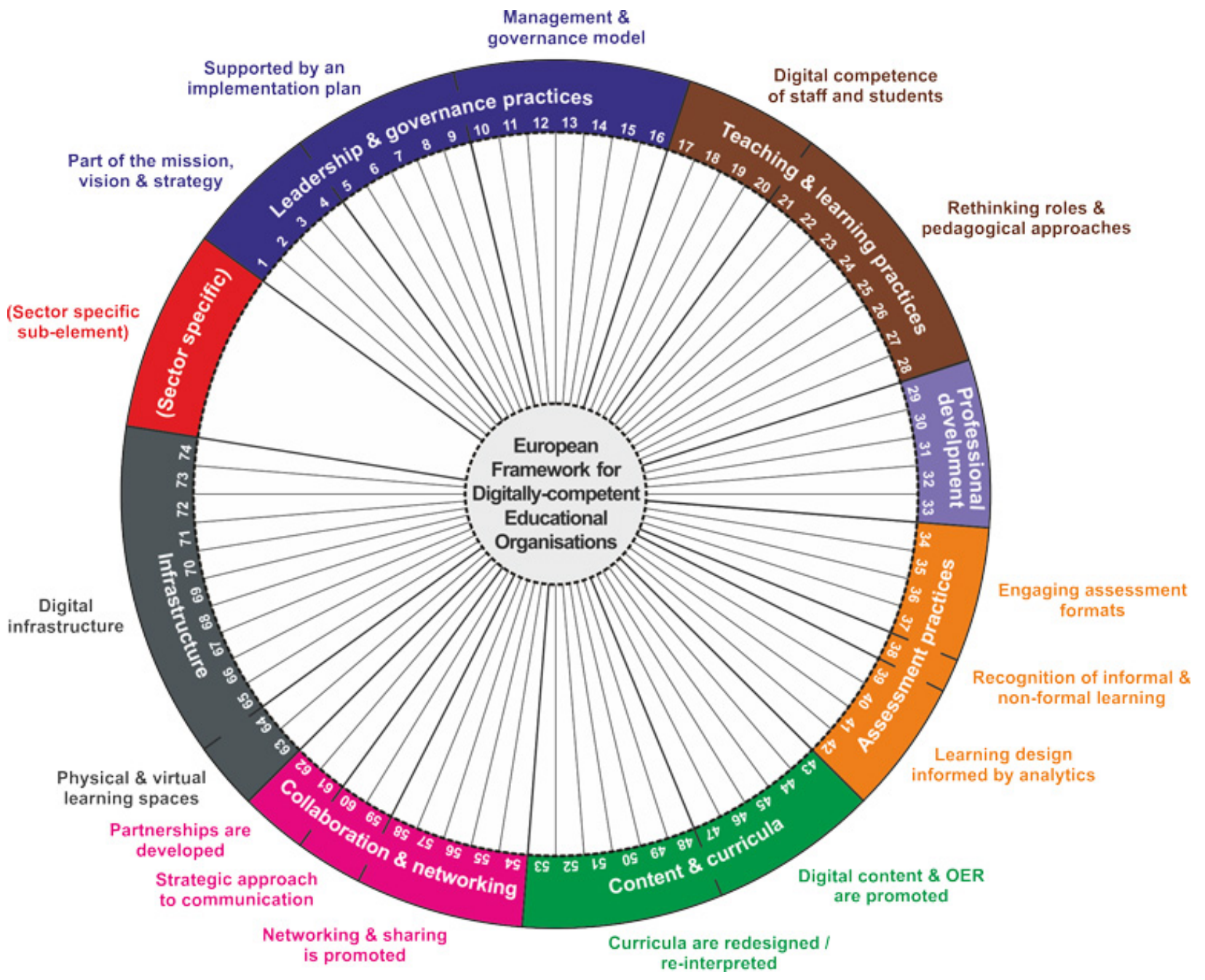

Source: Kampylis et al. [41] (p. 5).

Figure 1. European Reference Framework for Digitally-Competent Educational Organizations 
In their work released in 2020, on the topic of digital earth challenges and future trends, van Genderen et al. [42] offer insights on new opportunities and future trends in digital earth, and propose new technology trends, such as IoT, Blockchain, Virtual Reality/Augmented, Reality/Mixed Reality, Artificial Intelligence (AI), Hyper-Connectivity, 5G, Fog/Edge Computing, Progress in Computing and Microelectronics, and In-memory Computing.

The development of digital competences, such as creativity and innovation; communication and collaboration; research and information handling; critical thinking; digital citizenship; and informational literacy [43], may, hence, also add to the learning of a culture of sustainability [3].

The concept of sustainability has gone through several stages $[31,44,45]$ and encompasses the economic, social and environmental dimensions $[46,47,48,49]$. In a sustainable society, citizens are expected to develop eight key competences, detailed in Table 1 .

The digitalization process that runs through contemporary society [50] is translated, for example, into Society 5.0, which involves developing the potential of the individual-digital technology relationship in the development of sustainability, culminating in a smart society $[4,5]$ that may foster a "smart education" [51].

According to Sá and Serpa [14], UNESCO [52,53] advocates the critical importance of education in promoting and developing both Sustainable Development Goals (SDGs) and individual sustainability competences. In this context, SDG4 (quality education) takes on special relevance "for the achievement of sustainable development, and Education for Sustainable Development is particularly needed because it empowers learners to make informed decisions and act responsibly for environmental integrity, economic viability and a just society, for present and future generations" [53] (p. 63).

UNESCO [52,53] sustains that education is vital in fostering SDGs and sustainability competences. In particular, education is paramount in attaining sustainable development, and Education for Sustainable Development (ESD) is particularly needed, inasmuch that it enables students to make informed decisions and have responsible actions in terms of environmental integrity, economic viability and fair society, both for present and future generations [54]. Furthermore, it may foster a more active learning process in the part of the student [40].

Table 1. Eight key competences for sustainability.

\begin{tabular}{|c|}
\hline 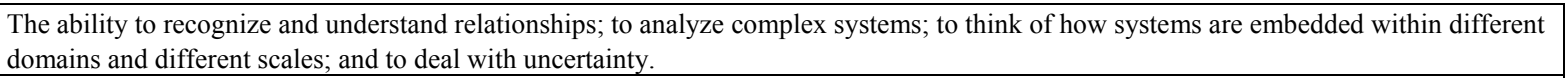 \\
\hline to "understand and evaluate multiple futures - possible, probable and desirable. \\
\hline $\begin{array}{l}\text { Normative competence, which relates to the ability to "understand and reflect on the norms and values that underlie one's actions; and to } \\
\text { negotiate sustainability values, principles, goals, and targets, in a context of conflicts of interests and trade-offs, uncertain knowledge and } \\
\text { contradictions". }\end{array}$ \\
\hline $\begin{array}{l}\text { Strategic competence, that is, the ability to "collectively develop and implement innovative actions that further sustainability at the local } \\
\text { level and further afield". }\end{array}$ \\
\hline $\begin{array}{l}\text { Collaboration, i.e., the ability to "learn from others; to understand and respect the needs, perspectives and actions of others (empathy); to } \\
\text { understand, relate to and be sensitive to others (empathic leadership); to deal with conflicts in a group; and to facilitate collaborative and } \\
\text { participatory problem solving". }\end{array}$ \\
\hline $\begin{array}{l}\text { Critical thinking competence, which involves the ability to "question norms, practices and opinions; to reflect on own one's values, } \\
\text { perceptions and actions; and to take a position in the sustainability discourse". }\end{array}$ \\
\hline $\begin{array}{l}\text { Self-awareness, which entails the need to "reflect on one's own role in the local community and (global) society; to continually evaluate and } \\
\text { further motivate one's actions; and to deal with one's feelings and desires". }\end{array}$ \\
\hline 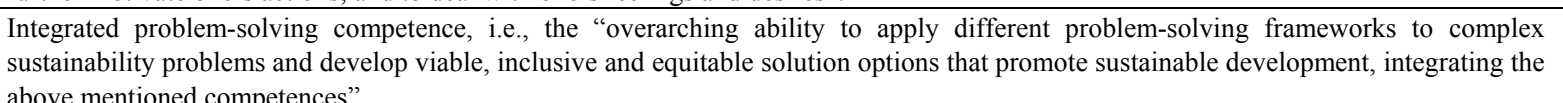 \\
\hline
\end{tabular}

Source: Adapted from UNESCO [53] (p. 10). 


\subsection{Fostering Digital Literacy through Education}

School culture will have to change more quickly in the path towards fostering education that, by mobilizing digital competences as a consumer but also as a content creator, adopts student-centered learning $[6,31,55,56]$ in a logic of participatory action-research [57].

Digital literacy itself is critical [28] as a skill to mobilize competences in the selection, apprehension and use of information that comes digitally through the Internet. However, there are inequalities regarding a school based on the digital virtual [58].

In the specific context of the COVID-19 pandemic, has called for school closures all around the world, with the associated impacts on millions of students. National governments tried to mitigate the consequences of school lockdown by developing online learning programs and distant education, but this has negatively affected disadvantaged children and youth, as not all have access to digital technologies. Furthermore, the care and supervision schools provide moved on to parents, with the consequent social-economic burden and the fact that many students were left unsupervised as their parents had to go to work [59]. In view of this scenario, "School closure measures should consider epidemiological evidence and avoid exacerbating inequities, providing learning without digital technologies, childcare alternatives, and health care, including nutritional programmes [sic]" [59] (p. e644). These inequalities call into question the formal principle of equality in access and school path [60].

Zhang, Wang, Yang, and Wang [61] offer a good example of a very well presented program, an emergency policy initiative launched by the Chinese government called "Suspending Classes without Stopping Learning". However, the authors warn of the various and serious challenges associated with this program, such as the online teaching infrastructure, the ability and experience of teachers, the information gap, the complex environment at home.

The authors [61] provide a set of suggestions on this process and how to improve it. Table 2 presents a summary of these suggestions.

This has, naturally, implications in terms of the national policies. Zhang et al. [61] put forth these implications and offer suggestions for the educational policies to be developed and enhanced in practice (Table 3 ).

Table 2. Suggestions to improve the promotion of digital literacy through education (“Suspending Classes without Stopping Learning” program)

\begin{tabular}{|c|c|}
\hline 1 & $\begin{array}{l}\text { Public emergency management is led and coordinated by the government and widely participated in by schools, enterprises and the } \\
\text { general public. }\end{array}$ \\
\hline 2 & $\begin{array}{l}\text { There have been many efforts by the government and society to predict problems that may arise in the process of policy implementation } \\
\text { and to search for corresponding solutions. }\end{array}$ \\
\hline 3 & $\begin{array}{l}\text { Despite the encouragement for local authorities and schools to adapt measures to local conditions (e.g. the slogan of "one school, } \\
\text { multiple policies"), this is difficult to address under time constraints, due to disparity in teacher quality and education resources across } \\
\text { schools, and a lack of mature and detailed plans for large-scale online education in emergency times. }\end{array}$ \\
\hline 4 & It is difficult to predict the duration of the emergency, creating a great challenge for educational activities. \\
\hline 5 & $\begin{array}{l}\text { "Suspending Classes Without Stopping Learning" is arguably an experiment in large-scale online education. The experiment } \\
\text { demonstrates big differences between, and the irreplaceability of, online and offline education. }\end{array}$ \\
\hline
\end{tabular}

Source: Adapted from Zhang et al. [61] (pp. 4-5).

Table 3. Implications and suggestions of the program "Suspending Classes without Stopping Learning"

\begin{tabular}{|c|l|}
\hline 1 & $\begin{array}{l}\text { The government should further promote the construction of the educational information superhighway, and test its functions, as well as } \\
\text { assess whether it can meet the demand for online teaching in times of emergency. }\end{array}$ \\
\hline 2 & $\begin{array}{l}\text { To equip teachers with standardized home-based teaching equipment across the country, especially with standardized electronic } \\
\text { devices to meet the needs of online teaching and individual tutoring in the home environment. Students' need for basic learning } \\
\text { equipment should also be considered. }\end{array}$ \\
\hline 3 & $\begin{array}{l}\text { To provide systematic training for teachers. Arguably the use of online platforms for high-quality teaching is an inevitable trend in the } \\
\text { Internet era. }\end{array}$ \\
\hline 4 & $\begin{array}{l}\text { To support and call for research into online education, at a national level, to enlighten approaches to effective online education. In } \\
\text { addition, to encourage and support social organizations and schools to play their roles fully is also of paramount importance. }\end{array}$ \\
\hline 5 & $\begin{array}{l}\text { One of the most pressing current tasks is to conduct in-depth investigations into online education, especially concerning student } \\
\text { support. }\end{array}$ \\
\hline
\end{tabular}

Source: Adapted from Zhang et al. [61] (p. 5). 
Interdisciplinarity is vital in this process [31,62]. On the one hand, curriculum design has to involve numerous stakeholders, such as educational leaders, academics, students and employers, among others. On the other hand, "To continue sustainability education through linear models is to limit students' abilities to make connections, establish relationships, communicate their work and truly understand the complexity of sustainability" [6] (p. 31).

Interdisciplinarity is, then, vital in this process, in which different stakeholders intervene $[6,31,62]$.

Zhu and Liu [63], applying their vision to the Chinese context - as well as other authors - deem essential, among others:

- $\quad$ to provide for open educational platforms that allow students and teachers to access high-quality learning tools;

- to carry out quantitative and qualitative research and assess current models of online teaching-learning processes;

- to develop in teachers the ability to carry out for online teaching and in the non-teaching staff the ability to support teachers and online systems;

- to encourage cooperation between universities, national and international organizations, the public and private sectors, civil society and other stakeholders, with the purpose of fostering high-quality online learning;

- to allocate investments and funds to distant learning to invest in modern technology;

- to arrange for flexible learning sessions, accommodating targeted students time schedules;

- to arrange for online exams to distant learning the students;

- to start or improve the existing educational TV channels and broadcast programs for 24 hours a day, to increase the learner's flexibility to learn;

- to digitalize all the libraries and made all the books available on the Internet to all stakeholders.

\section{Conclusions}

In the contemporary digital society, the school needs to reinvent itself, which is even more pressing with the Covid-19 pandemic [63]. Aspects such as training, internet access infrastructure, hardware and software, digital literacy, and students and academics' teaching and learning strategies are essential in this shift. The cultural diversity of schools and other educational institutions takes on a fundamental role. As Putri, Mirzania, and Hartanto [64] (p. 51) argue,

"This is the responsibility of a leader in determining the shared culture that will be believed and applied by each member of the organization. A leader who is responsible for an organization that accommodates cross-cultural employees is expected to be able to manage that diversity well".
The school offers, thus, a critical contribution to social cohesion and social equity through digital inclusion in education for sustainable development. The benefits of digitalization for sustainable development are undeniable, and only those countries and systems that fully embrace an education that fosters digital competences will equip their citizens with the competences needed for them to thrive and succeed both in the personal and professional spheres.

\section{Funding}

This work is financed by national funds through FCT Foundation for Science and Technology, I.P., within the scope of the project «UIDB 04647/2020» of CICS.NOVACentro Interdisciplinar de Ciências Sociais da Universidade Nova de Lisboa.

\section{REFERENCES}

[1] Sá, M. J., \& Serpa, S. (2020). The global crisis brought about by SARS-CoV-2 and its impacts on education: An overview of the Portuguese panorama. Science Insights Education Frontiers, 5(2), 525-530. https://doi.org/10.15354/sief.20.ar 039

[2] Melentieva, Y. P. (2020). Digital reading: Genealogy of formation and prospects for its development in a digitalized society. Bibliosphere, 4, 14-21. https://doi.org/10.20913/18 15-3186-2019-4-14-21

[3] ElMassah, S., \& Mohieldin, M. (2020). Digital transformation and localizing the Sustainable Development Goals (SDGs). Ecological Economics, 169, 106490. http://doi.org/10.1016/j.ecolecon.2019.106490

[4] Ferreira, C. M., \& Serpa, S. (2018). Society 5.0 and social development: Contributions to a discussion. Management and Organizational Studies, 5(4), 26. https://doi.org/10.543 $0 / \operatorname{mos} . v 5 \mathrm{n} 4 \mathrm{p} 26$

[5] Gladden, M. E. (2019). Who will be the members of Society 5.0? Towards an anthropology of technologically posthumanized future societies. Social Sciences, 8(5), 148. https://doi.org/10.3390/socsci8050148

[6] Bernier, A. (2017). From linear industrial structures to living systems: A design shift in education for sustainability. Education Sciences, 7(2), 43. https://doi.org/10.3390/educs ci7020043

[7] Daniel, S. J. (2020). Education and the COVID-19 pandemic. Prospects. https://doi.org/10.1007/s11125-020-09464-3

[8] López-Belmonte, J., Pozo-Sánchez, S., Fuentes-Cabrera, A., \& Trujillo-Torres, J.-M. (2019). Analytical competences of teachers in big data in the era of digitalized learning. Education Sciences, 9(3), 177. https://doi.org/10.3390/educ sci9030177

[9] Mavrou, K., Meletiou-Mavrotheris, M., Kärki, A., Sallinen, M., \& Hoogerwerf, E.-J. (2017). Opportunities and challenges related to ICT and ICT-AT use by people with 
disabilities: An explorative study into factors that impact on the digital divide. Technology and Disability, 29(1-2), 63-75. https://doi.org/10.3233/TAD-170174

[10] Raitskaya, L., \& Tikhonova, E. (2019). Skills and competencies in higher education and beyond. Journal of Language and Education, 5(4), 4-8. https://doi.org/10.1732 3/jle.2019.10186

[11] Gruzina, Y. M., Mel'nichuk, M. V., \& Belogash, M. A. (2020). Leadership ideas shaped by digital insights in higher education. Management Science, 9(4), 75-84. https://doi.org/10.26794/2404-022X-2019-9-4-75-84

[12] Strielkowski, W. (2020). COVID-19 pandemic and the digital revolution in academia and higher education. Preprints, https://doi.org/10.20944/preprints202004.0290.v1

[13] Napal Fraile, M., Peñalva-Vélez, A., \& Mendióroz Lacambra, A. (2018). Development of digital competence in secondary education teachers' training. Education Sciences, 8(3), 104. https://doi.org/10.3390/educsci8030104

[14] Sá, M. J., \& Serpa, S. (2018). Transversal competences: Their importance and learning processes by higher education students. Education Sciences, 8(3), 126. https://doi.org/10.3 390/educsci8030126

[15] Cantabrana, J. L. L., Minguell, M. E., \& Tedesco, J. C. (2015). Inclusion and social cohesion in a digital society. International Journal of Educational Technology in Higher Education, 12, 44-58. https://doi.org/10.7238/rusc.v12i2.2459

[16] Kalkan, Ü., Altınay Aksal, F., Altınay Gazi, Z., Atasoy, R., \& Dağl1, G. (2020). The relationship between school administrators' leadership styles, school culture, and organizational image. SAGE Open, 10(1), 215824402090208.

https://doi.org/10.1177/2158244020902081

[17] Santos, J. V., \& Gonçalves, G. (2018). Organizational culture, internal marketing, and perceived organizational support in Portuguese higher education institutions. Revista de Psicología Del Trabajo y de Las Organizaciones, 34(1), 38-41. https://doi.org/10.5093/jwop2018a5

[18] Serpa, S. (2016). An overview of the concept of organisational culture. International Business Management, 10. 51-61. Retrieved from http://medwelljournals.com/abstr act/?doi=ibm.2016.51.61

[19] Warter, L. (2019). The impact of organizational culture in higher education. Case study. Journal of Intercultural Management and Ethics, 2, 173-200. https://doi.org/10.35478/jime.2019.2.15

[20] Gebretsadik, D. M. (2020). Impact of organizational culture on the effectiveness of public higher educational institutions in Ethiopia. International Journal of Leadership in Education, 1-20. https://doi.org/10.1080/13603124.2020.1722248

[21] Caliskan, A., \& Zhu, C. (2019). Organizational culture type in Turkish universities using OCAI: Perceptions of students. Journal of Education Culture and Society, 10(2), 270-292. https://doi.org/10.15503/jecs20192.270.292

[22] Caliskan, A., \& Zhu, C. (2020). Organizational culture and educational innovations in Turkish higher education: Perceptions and reactions of students. Educational Sciences: Theory \& Practice, 20(1), 20-39.https://doi.org/10.12738/je stp.2020.1.003

[23] Dolamore, S., \& Richards, T. N. (2020). Assessing the organizational culture of higher education institutions in an era of \#MeToo. Public Administration Review. https://doi.org/10.1111/puar.13179

[24] Murunga, E. S., \& Karugu, J. E. (2019). Organizational culture and strategy execution at commission for university education, Kenya. International Journal of Current Aspects, 3(V), 76-90. https://doi.org/10.35942/ijcab.v3iV.62

[25] Ozcan, O., \& Ozturk, I. (2020). Impact of organizational culture and leadership styles on employee performance: a research study on the banking industry. Pressacademia, 7(1), 45-55. https://doi.org/10.17261/Pressacademia.2020.1187

[26] Deal, T. E., \& Peterson, K. D. (2016). Shaping school culture (3rd Ed.). San Francisco, CA: Jossey Bass.

[27] Jerald, C. D. (2006). School culture: "The hidden curriculum". The Center for Comprehensive School Reform and Improvement. Retrieved from https://files.eric.ed.gov/fulltext/ED495013.pdf

[28] Santos, A. I., \& Serpa, S. (2017). The importance of promoting digital literacy in higher education. International Journal of Social Science Studies, 5(6), 90. https://doi.org/10.11114/ijsss.v5i6.2330

[29] Ramsetty, A., \& Adams, C. (2020). Impact of the digital divide in the age of COVID-19. Journal of the American Medical Informatics Association, ocaa078. https://doi.org/1 0.1093/jamia/ocaa078

[30] Andrade, M. S. (2016). Curricular elements for learner success -21 st century skills. Journal of Education and Training Studies, 4(8), 143-149. https://doi.org/10.11114/jet s.v4i8.1743

[31] Serpa, S., \& Sá, M. J. (2019). Exploring sociology of education in the promotion of sustainability literacy in higher education. The Journal of Social Sciences Research, 51, 101-116. https://doi.org/10.32861/jssr.51.101.116

[32] Cartelli, A., Dagiene, V., \& Futschek, G. (2010). Bebras contest and digital competence assessment. International Journal of Digital Literacy and Digital Competence, 1(1), 24-39. http://doi.org/10.4018/jdldc.2010101902

[33] Klassen, A. (2019). Deconstructing paper-lined cubicles: Digital literacy and information technology resources in the workplace. International Journal of Advanced Corporate Learning (iJAC), 12(3), 5. https://doi.org/10.3991/ijac.v12i 3.11170

[34] Ferrari, A. (2012). Digital competence in practice: An analysis of frameworks. Luxembourg: Publications Office of the European Union.

[35] European Commission (2018). Human capital. Digital inclusion and skills. Digital Economy and Society Index Report 2018. Human Capital. Retrieved from https://ec.europa.eu/digital-single-market/en/human-capital.

[36] Pötzsch, H. (2019). Critical digital literacy: Technology in education beyond issues of user competence and labour-market qualifications. tripleC, 17(2), 221-240. https://doi.org/10.31269/triplec.v17i2.1093

[37] Sampson, D., Ifenthaler, D., Spector, J. M., \& Isaías, P. (Eds.) 
(2018). Digital technologies: Sustainable innovations for improving teaching and learning. Cham: Springer. https://doi.org/10.1007/978-3-319-73417-0

[38] Kampylis, P., Punie, Y., \& Devine, J. (2015). Promoting effective digital-age learning - A European framework for digitally-competent educational organisations. https://doi.org/10.2791/54070

[39] Vītoliņa, I. (2015). E-inclusion process and societal digital skill development. Discourse and Communication for Sustainable Education, 6(1), 86-94. https://doi.org/10.1515/ dcse-2015-0006

[40] Gomez Zermeño, M. G. (2020). Massive open online courses as a digital learning strategy of education for sustainable development. Journal of Sustainable Development of Energy, Water and Environment Systems. http://dx.doi.org/10.13044/j.sdewes.d7.0311

[41] Záklasník, M., \& Putnová, A. (2019). Digital society Opportunity or threat? Case studies of Japan and the Czech Republic. Acta Universitatis Agriculturae et Silviculturae Mendelianae Brunensis, 67(4), 1085-1095. https://doi.org/10.11118/actaun201967041085

[42] van Genderen, J., Goodchild, M. F., Guo, H., Yang, C., Nativi, S., Wang, L., \& Wang, C. (2020). Digital earth challenges and future trends. In H. Guo, M. Goodchild, \& A. Annoni (Eds), Manual of digital earth (pp. 811-827). Singapore: Springer.

[43] Rodrigo Moriche, M. P, Goig Martínez, R., Martínez Sánchez, I., \& Freitas Cortina, A. (2020). La competencia digital en los programas de formación de ocio y tiempo libre para jóvenes [Digital competence in leisure training programmes for young people]. Pedagogia Social Revista Interuniversitaria, 35, 139. http://dx.doi.org/10.7179/psri_2 020.35 .11

[44] Lozano, R., Merrill, M., Sammalisto, K., Ceulemans, K., \& Lozano, F. (2017). Connecting competences and pedagogical approaches for sustainable development in higher education: A literature review and framework $\begin{array}{llll}\text { proposal. } & \text { Sustainability, } & 9(10), & 1889 .\end{array}$ https://doi.org/10.3390/su9101889

[45] Ruiz-Mallén, I., \& Heras, M. (2020). What sustainability? Higher education institutions' pathways to reach the Agenda 2030 Goals. Sustainability, 12(4), 1290. https://doi.org/10.3 390/su12041290

[46] United Nations (2015). Resolution adopted by the General Assembly on 25 September 2015. 70/1. Transforming our world, The 2030 agenda for sustainable development. Retrieved from http://www.un.org/ga/search/view_doc.asp? symbol=A/RES/70/1\&Lang $=\mathrm{E}$

[47] United Nations (2018). About the sustainable development goals. Retrieved from https://www.un.org/sustainabledevel opment/sustainable-development-goals/

[48] United Nations (2019). Global indicator framework for the Sustainable Development Goals and targets of the 2030 Agenda for Sustainable Development. Retrieved from https://unstats.un.org/sdgs/indicators/Global\%20Indicator\% 20Framework\%20after\%202019\%20refinement_Eng.pdf

[49] Mensah, J., \& Casadevall, S. R. (2019). Sustainable development: Meaning, history, principles, pillars, and implications for human action: Literature review. Cogent
Social Sciences, 5(1), 1653531. https://doi.org/10.1080/233 11886.2019.1653531

[50] Abad-Segura, E., González-Zamar, M.-D., Infante-Moro, J. C., \& Ruipérez García, G. (2020). Sustainable management of digital transformation in higher education: Global research trends. Sustainability, 12(5), 2107. https://doi.org/10.3390/su12052107

[51] Krajčo, K., Habánik, J., \& Grenčíková, A. (2019). New technology impact on the sustainable development. Engineering Economics, 30(1). https://doi.org/10.5755/j01. ee.30.1.20776

[52] UNESCO (2016) Education 2030. Incheon Declaration and framework for action. Ensure inclusive and equitable quality education and lifelong learning for all. Paris: UNESCO.

[53] UNESCO (2017). Education for sustainable development goals. Learning objectives. Paris: United Nations, Educational, Scientific and Cultural Organization.

[54] Farinha, C., Caeiro, S., \& Azeiteiro, U. (2019). Sustainability strategies in Portuguese higher education institutions: Commitments and practices from internal $\begin{array}{llll}\text { insights. } & \text { Sustainability, } & 11(11), & 3227\end{array}$ https://doi.org/10.3390/su11113227

[55] López-Meneses, E., Sirignano, F. M., Vázquez-Cano, E., \& Ramírez-Hurtado, J. M. (2020). University students' digital competence in three areas of the DigCom 2.1 model: A comparative study at three European universities. Australasian Journal of Educational Technology, 69-88. https://doi.org/10.14742/ajet.5583

[56] Tejedor, G., Segalàs, J., Barrón, Á., Fernández-Morilla, M., Fuertes, M., Ruiz-Morales, J., ... Hernández, À. (2019). Didactic strategies to promote competencies in sustainability. Sustainability, 11(7), 2086. https://doi.org/10.3390/su11072 086

[57] Serpa, S., Ferreira, C. M., Santos, A. I., \& Teixeira, R. (2018). Participatory action research in higher education training. International Journal of Social Science Studies, 6(6), 1. https://doi.org/10.11114/ijsss.v6i6.3286

[58] von Braun, J., Zamagni, S., \& Sorondo, M. S. (2020). The moment to see the poor. Science, 368(6488), 214. https://doi.org/10.1126/science.abc2255

[59] Armitage, R., \& Nellums, L. B. (2020). Considering inequalities in the school closure response to COVID-19. The Lancet Global Health, 8(5), e644. https://doi.org/10.10 16/S2214-109X(20)30116-9

[60] Cherkaoui, M. (1999). Sociologie de l'éducation [Sociology of education]. Paris: Presses Universitaires de France.

[61] Zhang, W., Wang, Y., Yang, L., \& Wang, C. (2020). Suspending Classes Without Stopping Learning: China's education emergency management policy in the COVID-19 outbreak. Journal of Risk and Financial Management, 13(3), 55. https://doi.org/10.3390/jrfm13030055

[62] Brudermann, T., Aschemann, R., Füllsack, M., \& Posch, A. (2019). Education for sustainable development 4.0: Lessons learned from the University of Graz, Austria. Sustainability, 11(8), 2347. https://doi.org/10.3390/su11082347

[63] Zhu, X., \& Liu, J. (2020). Education in and after Covid-19: Immediate responses and long-term visions. Postdigital 
Science and Education. https://doi.org/10.1007/s42438-020 $-00126-3$

[64] Putri, S. A., Mirzania, A., \& Hartanto, D. (2020). The importance of a transformational leadership model in managing organizational culture. Journal of Leadership in Organizations, 2(1), 49-56. https://doi.org/10.22146/jlo.495 29. 